\title{
ENVIRONMENTAL IMPACTS OF HERBICIDE TOLERANT CROPS AND GLYPHOSATE-BASED HERBICIDES - A REVIEW
}

\author{
Velmourougane, K. ${ }^{*}$ - Blaise, D. - Manikandan, A. - Savitha, S. - Waghmare, V. N. \\ ICAR - Central Institute for Cotton Research, Post Bag. No. 2, Shankar Nagar Post, Nagpur- \\ 440 010, Maharashtra, India \\ (phone: +91-07103-275549; fax: +91-07103-2275-529) \\ *Corresponding author \\ e-mail:velicar@gmail.com
}

(Received $19^{\text {th }}$ Apr 2021; accepted $19^{\text {th }}$ Jul 2021)

\begin{abstract}
Glyphosate is a broad-spectrum, non-selective, contact herbicide, dominating the global pesticide market and the most widely used agricultural chemicals worldwide, to manage pre- and postemergence weeds. Despite the fact that glyphosate and glyphosate-based herbicides are widely used, and claimed as a "once in a century herbicide", there remains extensive debate on the consequences of glyphosate usage and its impacts on soil, plant, and environmental health, apart from non-targeted vegetation. Though positive effects of glyphosate on agricultural food production, soil conservation and environmental pollution have been put forth by several workers, glyphosate and its negative impacts on the environment, especially its persistence in soils, the emergence of glyphosate-resistant weeds, and its integration into the existing cropping systems in agroecosystems remains a challenge. In this review, we provide updates on glyphosate and glyphosate-based herbicides, and their impacts on the environment, which will be highly useful for researchers and decision-makers to establish policies for glyphosate and glyphosate-based herbicide usage in agriculture.
\end{abstract}

Keywords: glyphosate, soil persistence, health impacts, soil functions, food chain, microbial and faunal diversity

\section{Introduction}

Glyphosate (N-(phosphonomethyl) glycine) is a broad-spectrum, nonselective, contact (foliar-applied) herbicide. Glyphosate was commercialized in 1974, and has been widely used to control pre- and post-emergence weeds (grass and broadleaved weeds) in agriculture (Nandula, 2010). Glyphosate inhibits the enzyme 5-1-enolpyruvylshikimate-3-phosphate synthase (EPSPS) involved in the shikimate pathway, leading to build up of shikimate and reducing the synthesis of aromatic amino acids, which are necessary for plant survival (Duke and Powles, 2008). Herbicide-tolerant (HT) crops consistently occupy the largest area of genetically modified (GM) crops, and the most frequently used HT crops are engineered to express cp4-epsps, the product of which is not inhibited by the herbicide, "glyphosate" (Duke, 2005). Glyphosate based herbicides (GBHs) are at present the most heavily applied herbicides in the world, and the use of GBHs is likely to rise on the event of approval of Roundup Ready glyphosate-tolerant, worldwide (Benbrook, 2012). The countries that have approved HT include Argentina, Australia, Brazil, Canada, China, Colombia, Costa Rica, EU, Japan, Malaysia, Mexico, New Zealand, Paraguay, Philippines, Singapore, South Africa, South Korea, Taiwan, USA (James, 2003). Depending on weed species, plant type, and other biotic or abiotic factors, the recommended rates of glyphosate vary largely. Consequently, enormous amounts of glyphosate enter the environment every year, and concern has grown over its possible ecological impacts (Myers et al., 2016). Glyphosate, GBHs, and HT crops are expected to affect soil, 
plants, environment, and human well-being directly or indirectly (Fig. 1). With this background, in this review, we discuss the impacts of HT crops and GBHs on the environment in detail.
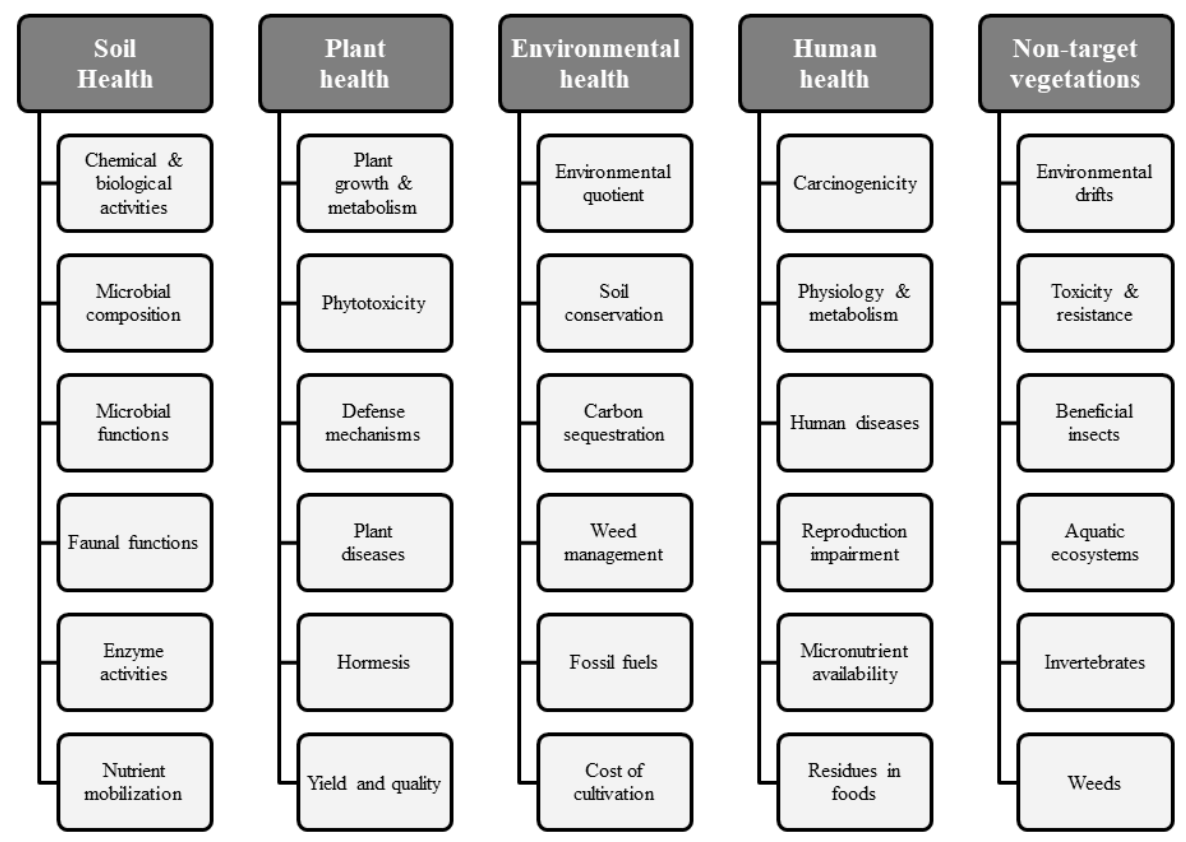

Figure 1. Possible impacts of herbicide tolerant crops and glyphosate-based herbicides

\section{Glyphosate in food supply chain and its health impacts}

Since the glyphosate is the most widely used herbicide in the environment (Kier and Kirkland, 2013), its long-term use at global scale, not only affect the soil, water, and air, but its entry into the food chain through ingestion are of great health concerns (Bai and Ogbourne, 2016; Torretta et al., 2018) (Fig. 2). Glyphosate residues have been detected in several environmental samples such as water, air, food, and feed through drifting, leaching, and surface runoff (Mensah et al., 2012). Furthermore, the drift and dispersal of glyphosate in the soil-water environment can damage-living organisms including aquatic life (Williams et al., 2000; Bailey et al., 2017). Several studies have shown that the absorption constant of the chemical varies between 8 and $377 \mathrm{dm}^{3} \mathrm{~kg}^{-1}$, depending on the soil characteristics. In water, the half-life of glyphosate shown to vary from a few days to 91 days (Vereecken, 2005; Borggaard and Gimsing, 2008). The time of application also plays a primary role in residue levels in the final product. For example, glyphosate application during harvest has been reported to increase the residue levels in soybeans (Duke et al., 2003; Arregui et al., 2004).

The glyphosate residues were reported from animal feed, animal urine, animal flesh, human food, human milk, and human urine (Acquavella et al., 2004; Borggaard and Gimsing, 2008; Krüger et al., 2013, 2014; Niemann et al., 2015), indicating greater release of glyphosate-salts (isopropyl amine, glyphosate- ammonium, glyphosatesesquisodium, and glyphosate-trimesium) into the environment, and subsequent entry into food supply chain of increased exposure to glyphosate (Cuhra et al., 2016). In a human exposure study, involving occupationally and para-occupationally exposed subjects, the average urinary levels of glyphosate varied from 0.26 to $73.5 \mu \mathrm{g} / \mathrm{L}$ in 
occupationally exposed subjects. While, the environmental exposure urinary levels ranged from 0.16 to $7.6 \mu \mathrm{g} / \mathrm{L}$ (Gillezeau et al., 2019). Worst case exposure causing acute poisoning (cardiorespiratory toxicity) in adult humans has been reported to be 125 and $5 \mu \mathrm{g} \mathrm{kg}^{-1} \mathrm{day}^{-1}$ for glyphosate and aminomethylphosphonic acid (AMPA), respectively (Williams et al., 2000). Several studies have demonstrated the possible entry route of glyphosate in the gastro-intestinal tract of humans and mammals, through inhalation, ingestion, and dermal contact affecting growth, kidney and liver functions, lymphoma, etc. (Peillex and Pelletier, 2020). Glyphosate and GBHs provoke oxidative damage in rats (liver and kidneys) through the disruption of mitochondrial metabolism at exposure levels, which is currently considered safe (Mesnage et al., 2015). Further, studies detected higher levels of glyphosate and AMPA in the tissues of farm animals compared to their usual levels in fat, and increased frequency of kidney disease among the male agricultural workers, who were exposed to heavy GBHs uses (Jayasumana et al., 2014). In vertebrates, glyphosate and GBHs interrupted endocrine-signaling systems and steroid hormones (Thongprakaisang et al., 2013). GBHs are linked to increased risk of developing non-Hodgkin's Lymphoma (NHL) among humans (Schinasi and Leon, 2014). As a chelating agent, glyphosate and GBHs can affect micronutrient availability to living beings, including crops and animals (Johal and Huber, 2009).

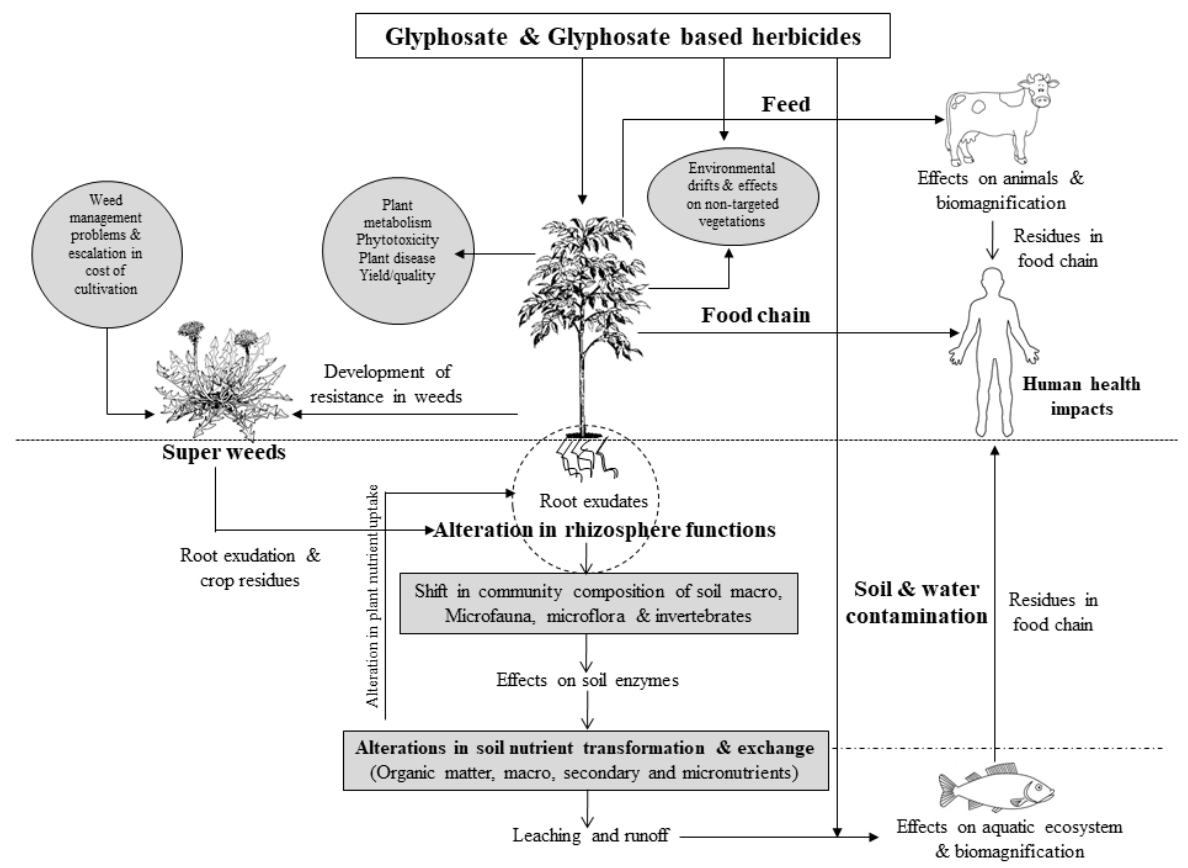

Figure 2. Environmental fate of glyphosate and glyphosate-based herbicides

Similarly, in plants, glyphosate altered the functions such as photosynthesis, respiration, and the synthesis of essential aromatic amino acids (Williams et al., 2000; Samsel and Seneff, 2013; Kruger et al., 2014; Bailey et al., 2017). Traces of glyphosate have been recorded in wheat flour, oats, bread (Székács and Darvas, 2012), honey (Rubio et al., 2014), and beers (reuters.com). In Italy, 100 food products based on flour (corn flakes, rusks, pasta, spaghetti) and 26 samples of drinking water showed traces of glyphosate (Corvino, 2015; Test-Salvagente, 2016). Human milk showed glyphosate 
presence in the range of 76 to $166 \mu / \mathrm{L}$. However, this level is considered acceptable by the Environmental Protection Agency (EPA) (momsacrossamerica.com). Traces of glyphosate were detected in $85 \%$ of tampons, medical gauze (cotton), panty liners (ecowatch. com; reuters.com). In Germany, human urine samples contained traces of glyphosate in the range of 0.17 to $3.5 \mu / \mathrm{L}$ (slowfood.com). Similarly, the children and young people who had worked in the agricultural sector found have higher traces of glyphosate in their urine (foodnavigator.com).

The US Environmental Protection Agency (USEPA) classified glyphosate as a suspected human carcinogen (Category C) in 1985. However, long-term administration studies showed limited evidence of carcinogenicity in animals and inadequate data on humans' carcinogenicity (Rubio et al., 2014). Subsequently, in 1991, EPA included glyphosate in the E category (substances that do not show carcinogenic potential) based on animal and epidemiological studies (www.epa.gov). In 2015, the International Agency for Research on Cancer (IARC) classified glyphosate as "probably carcinogenic to humans", with the insertion of the 2A category (substances with limited evidence of carcinogenicity to humans and sufficient evidence for animals) (IARC, 2015). In 2015, based on the technical assessment of glyphosate by an institution of a member state (German Federal Institute for Risk Assessment-BfR), the European Food Safety Authority (EFSA) concluded that it was "improbable" that the pesticide was genotoxic or carcinogenic to humans (EFSA, 2015). However, subsequent analyses of the toxicological data have concluded that glyphosate is unlikely to pose a genotoxicity or carcinogenic risk to humans (EFSA, 2017; USEPA, 2019). Subsequently, the EFSA proposed new toxicological safety thresholds to improve the control of glyphosate residues in food i.e. (i) Increasing the ADI (Acceptable Daily Intake) or DGA, that is the daily human consumption limit, from $0.03 \mathrm{mg} / \mathrm{kg}$ to $0.05 \mathrm{mg} / \mathrm{kg}$, in line with the acute reference dose (ARD), always fixed at $0.05 \mathrm{mg} / \mathrm{kg}$ body weight, (ii) The admissible exposure level of the operator (Laeo) was fixed at $0.01 \mathrm{mg} / \mathrm{kg}$ of body weight per day (www.efsa.europa.eu). Later, in 2016, the joint expert committee of FAO-WHO on pesticide residues in the environment and food, concluded that "glyphosate is unlikely to lead to carcinogenic risk for humans as a consequence of exposure through the diet" (FAO, 2016).

\section{Persistence, degradation and residual effects}

The microbial action is the primary mode of glyphosate mineralization in the soils, and the glyphosate rapidly degrades in the non-sterile than sterile soils, indicating the role of microorganisms in the glyphosate degradation (Borggaard and Gimsing, 2008). In most of the soils, the bulk of glyphosate and its primary metabolite (AMPA) is found on the surface soil (Okada et al., 2016), and the glyphosate does not readily move from most soils to either ground- or surface water (Borggaard and Gimsing, 2008), however, its leaching be faster in the soils with higher macropores (higher content of sand and gravel). On an average, $>1 \%$ of the glyphosate applied was reported to be lost as runoff. Compared to glyphosate, the AMPA presence in ground/surface water is much higher due to its mobile nature in the soils (Kjaer et al., 2005). GBHs contaminated drinking water via rainwater, surface runoff and leaching into groundwater (Battaglin et al., 2014). Spraying of higher doses of glyphosate above the recommended levels is reported to cause higher runoff. However, glyphosate in surface water was reported to ultimately adsorb onto the soil sediments, where it undergoes biological degradation (Wang et al., 
2016). Though a small body of literature discusses the bioremediation of soils with high glyphosate content (Zhan et al., 2018), no studies have reported the persistence of glyphosate and AMPA in soils with long-term use in glyphosate-resistant (GR) crops (Duke et al., 2018). Further, the lack of crop yield reduction in soils with long-term usage of glyphosate indicates that if glyphosate has accumulated in such soils, it is not bioavailable as a herbicide (Duke et al., 2018; Reddy et al., 2018).

The glyphosate and its metabolites are readily water-soluble, which makes them difficult to build up or bio-magnify in nature (Duke, 2020). Glyphosate is mineralized via two enzymatic routes in soils; the major one is by glyphosate oxidoreductase, which produces AMPA and glyoxylate (Fig. 3). Glyoxylate is a common metabolic compound, whereas AMPA found in the environment comes from the glyphosate degradation and degradation of phosphorus containing detergents (Botta et al., 2009). The second route of degradation is through a carbon-phosphorus (C-P) lyase that produces sarcosine $(\mathrm{N}$ methyl glycine) and inorganic- $\mathrm{PO}_{4}$. Alternatively, the transformation of glyphosate to AMPA and glyoxylate can also be performed by glycine oxidase (Pollegioni et al., 2011). Both glyoxylate and methylamine was shown to support the growth of microorganisms (Duke, 2011). The glyphosate degradation rate was reported to be faster in aerobic than anaerobic soils, with a half-life value of 1.0 to 67.7 days, and more than $85 \%$ of soilapplied glyphosate was reported to be mineralized within the first 44 days, and micromyces were reported to be the main contributor of glyphosate degradation (Alexa et al., 2010). In a broad-range of agricultural soils with different soil properties, $7 \%-70 \%$ of glyphosate degradation occurred in the first 32 days (Nguyen et al., 2018). There was no significant influence of tillage on the degradation of glyphosate, and around $40 \%$ of glyphosate applied was reported to dissipate by 3 days in the silt loam soils (Okada et al., 2019). The glyphosate mineralization rate was strongly correlated with soil exchangeable acidity $\left(\mathrm{H}^{+}\right.$and $\left.\mathrm{Al}^{3+}\right)$, exchangeable $\mathrm{Ca}^{3+}$ ions, and ammonium lactate-extractable potassium (Mertens et al., 2018).

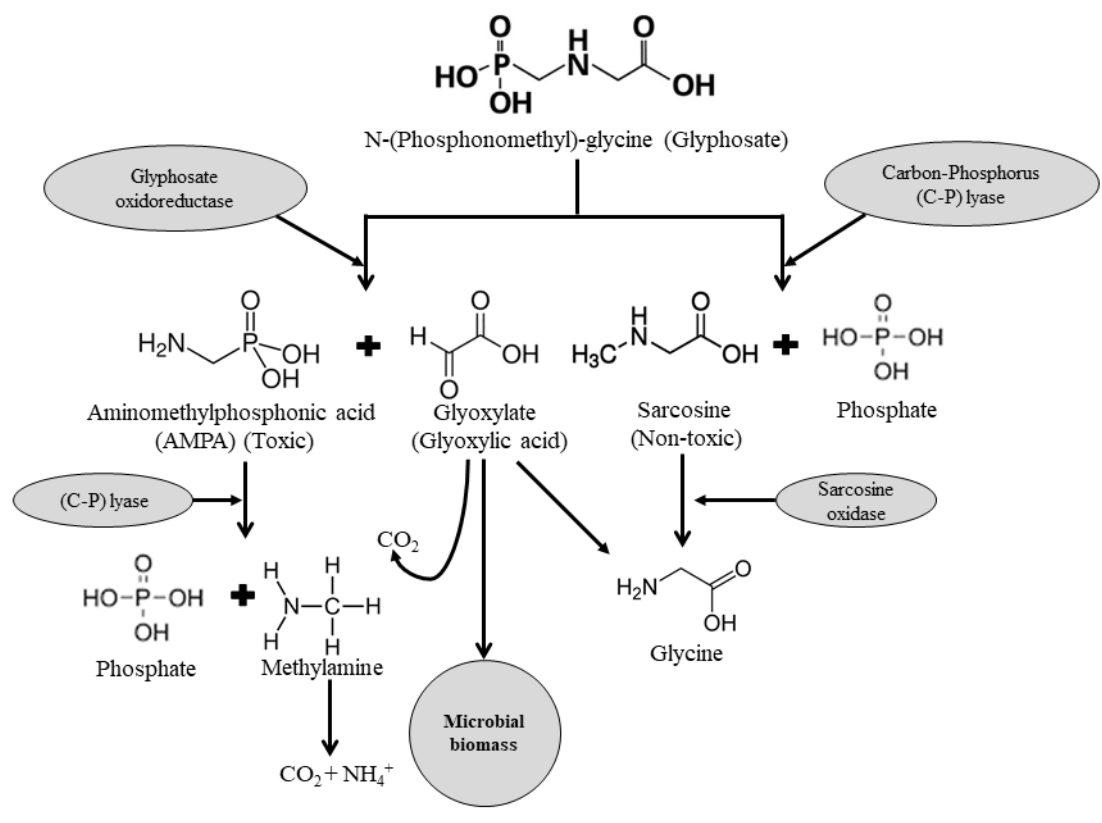

Figure 3. Degradation pathways of glyphosate

Glyphosate taken up by plants is reported to exude from roots or leached from plant residues (Laitinen et al., 2007). Glyphosate applied to GR and non-GR canola was 
reported to undergo a slow degradation process, thus increasing its persistence in the sprayed fields (Mamy et al., 2016). Glyphosate and AMPA residues were detected in Roundup Ready soybeans and with other associated crops such as wheat, barley, and vegetable crops (Bøhn et al., 2014). Based on their study on three soybean types (organic, conventional, and genetically modified), Bøhn et al. (2014) reported less total saturated fat and total omega- 6 fatty acids in organic-soybeans compared to conventional and GM-Soybeans. Further, high levels of glyphosate $\left(3.3 \mathrm{mg} \mathrm{kg}^{-1}\right)$ and AMPA $\left(5.7 \mathrm{mg} \mathrm{kg}^{-1}\right)$ residues were observed in GM-Soybeans. Though, a non-significant difference in residue decomposition rates of GR-soybean and a counterpart-sensitive soybean, glyphosate application was shown to decrease the decomposition rates at the top soils, but not in the sub-soil (Powell et al., 2009). Further, there were no much differences in ratios of fungal biomass to bacterial biomass in the degrading residues (Powell et al., 2009).

\section{Soil functions, environmental quality and environmental impact quotient}

The application of glyphosate to agricultural soil was shown to increase soil respiration by $42 \%$, while there was no clear effect on fluorescein diacetate hydrolysis (an indicator of microbial activity in soils) (Zabaloy et al., 2008). Glyphosate application also stimulate mineralization of native organic matter, carbon and nitrogen mineralization (Eser et al., 2007). There were no significant differences in soil microbial biomass (SMB), microbial respiration and nitrogen mineralization rate in soils with long-term glyphosate exposure (Busse et al., 2001). The application of glyphosate alters the organic carbon content in soils, thus influencing microbial population and their community composition (Imparato et al., 2016). However, a meta-analysis study concluded that the management and environmental factors play a significant role in soil microbial response to glyphosate application (Nguyen et al., 2106).

GBH (Roundup WeatherMax) was reported to affect soil microbial reaction to pesticides such as trifluralin, aldicarb, and mefenoxam+ pentachloronitrobenzene. Where, the soils exposed to glyphosate only exhibited greater cumulative carbon mineralization (Lancaster et al., 2008). Similarly, soil application of glyphosate + diflufenican was shown to inhibit the soil microbial biomass-Carbon (SMBC) and soil enzymes compared to the action of both the herbicides applied individually (Tejada, 2009). Growing GR-cotton, corn, and soybean did not affect the acid or alkaline phosphatase activities (Savin et al., 2009). The application of glyphosate had non-significant effects on soil dehydrogenase activity (DHA) (Zabaloy et al., 2008; Shitha, 2014). Glyphosate applications had a transient effect, without affecting the microbial community, metabolic activity, and soil exoenzyme's activities of the bulk and rhizosphere soil (Jenkins et al., 2017).

Though glyphosate applied to soils was reported to be absorbed by clay minerals, soil organic matter competes for glyphosate adsorption sites, and inhibit its adsorption in clay minerals (Gerritse et al., 1996). Glyphosate was also reported to compete with phosphate, which results in phosphorus runoff after one day of amendment (Sasal et al., 2015). Glyphosate application in soil was found not to effect on exchangeable potassium (available to plant) and non-exchangeable potassium (Lane et al., 2012), and no residual toxicity of K-salt of glyphosate was observed (Kaur and Walia, 2014). Glyphosate as a strong chelating agent, form complexes with minerals and ions, such as calcium, magnesium, manganese, iron, zinc present in soil and water, and subsequently 
make those micronutrients unavailable to plants through immobilization causing nutrient deficiencies (Glass, 1984). Complexing of $\mathrm{Mn}+$ glyphosate inside the plant was reported to reduce its bioavailability in soybean (Bott et al., 2008). Alternatively, some complexed ions reach plants through absorption causing ill effects in long-term exposure (Samsel and Seneff, 2013). Likewise, glyphosate application was shown to affect the rhizospheric ratios of manganese-oxidizers to manganese-reducers in the GRsoybeans, resulting in reduced solubility of manganese in soil, and subsequent reduction in plant uptake (Johal and Huber, 2009).

The adoption of GR-crops was reported to reduce herbicide usage $\left(\mathrm{LC}_{50}\right)$ per hectare by 100 and 500 in soybeans and cotton, respectively (Gardner and Nelson, 2008). Similarly, worldwide cultivation of GR-soybeans, corn, and cotton was found to reduce the environmental impact quotient (EIQ) by 15\%, 13\%, and 9\%, respectively (Barfoot and Brookes, 2014). Consecutively, the EIQ values for GR-soybean, corn, cotton, canola, and sugar beet were reduced to $13 \%, 13 \%, 11 \%, 30 \%$, and $19 \%$, respectively, after two years of cultivation (Brookes and Barfoot, 2018). Though herbicide usage was found to be on the rise in corn, cotton, and soybeans in the United States, the associated herbicide acute hazard quotients declined after the adoption of GR-crops (Kniss, 2017). Among the herbicides used, the glyphosate contributed to $0.1 \%, 0.3 \%$, and $3.5 \%$ of the herbicide chronic toxicity quotients in corn, soybean, and cotton, respectively, suggesting its insignificant role in contributing to the toxicity hazard of its use in agriculture (Kniss, 2017). Further, non-adoption of glyphosate as a herbicide option in agriculture is estimated to increase the EIQ of herbicide use by $0.4 \%$ to $11.6 \%$ (Brookes, 2018).

\section{Soil conservation and carbon sequestration}

At present, tillage is the primary onfarm practice followed to manage weeds in several small and marginal farms. However, long-term tillage practices caused substantial soil loss through erosion and subsequent environmental damage. In addition, soil disturbance and its movement from crop fields to other water-bodies are expected to disrupt ecosystems. Though, use of glyphosate to manage weeds is reported to avoid soil tillage operations, whereby it conserves soil and ecosystems (Cerdeira and Duke, 2006). However, since glyphosate applications kill all weeds, use of GR-crops (including intercrops, cover crops and other cropping system-based crops) became inevitable. Lessing of tillage operations facilitated by the GR crops had led to the minimization of soil loss, environmental pollution and conservation of ecosystems (Duke and Powles, 2009). Though, the impact of reduced- and no-tillage (not ploughed) operations in agriculture on environmental deterioration by adoption of GR-crops or glyphosate application has not been well documented, the greater adoption of reducedand no-tillage operations due to GR-crops usage, and its effect on the development of GR-weeds, was well studied (Givens et al., 2009). Among several agricultural field operations, tillage was reported to contribute to higher $\mathrm{CO}_{2}$ production in agricultural systems. Further, the adoption of GR-crops was reported to reduce fossil fuel usage and associated pollution in agriculture, worldwide (Brookes and Barfoot, 2018). Further, recently, there is a stringent competition for agricultural lands to serve several crucial services including food crops, fibre crops, oilseed crops, vegetables, etc. These essential requirements have further worsened the need for lands for intensive agriculture due to recent soil quality loss, land degradation and climatic changes (Balmford et al., 2018). 
Non-adoption of glyphosate in agriculture also increase the demand for additional agricultural land to meet the global crop production (Brookes et al., 2017), which cost both farmers and the public (Duke and Powles, 2008; Duke, 2018).

\section{Development of glyphosate resistance in weeds}

Herbicides are one the most important plant protection chemicals, which help reducing labour cost (Travlos et al., 2017). However, increased shortage of work force in agriculture for cultural control of weed species, herbicide usage is on increasing trend in several crops including cotton, corn, and wheat due to the development of herbicideresistant weeds to commonly used herbicides in agriculture (Travlos et al., 2018). Furthermore, climate change and new cropping systems pose numerous new challenges in weed management in breaking down the development of resistance in weeds (Heap and Duke, 2018; Heap, 2020). Glyphosate is one of the most widely used herbicides globally for both agricultural and nonagricultural applications (Andert et al., 2019) accounting for one-third of the total herbicide usage in agriculture (Székács and Darvas, 2018). The over dependence on glyphosate usage in agriculture has caused the development of weeds resistant to glyphosate (Gonzalez-Torralva et al., 2012; Singh et al., 2020). Presently, around 48 glyphosate-resistant species have been reported worldwide, resulting in low herbicidal efficacy on weeds and higher weed management costs (Heap and Duke, 2018; Heap, 2020). The first case of glyphosate resistance in tall windmill grass (Chloris elata) was reported in Cuba (Bracamonte et al., 2017). Fernandez-Moreno et al. (2017a) reported the glyphosate resistance in perennial ryegrass (Lolium perenne) and Italian ryegrass (L. multiflorum). Glyphosate-resistant weed species were common in four weed families (Poaceae, Asteraceae, Amaranthaceae, and Chenopodiaceae) compared to other primary weed species (Heap and Duke, 2018). The genera Lolium (perennial ryegrass), Chloris (feathery Rhodesgrass or windmill grass), and Bromus (brome grass) in the Poaceae family; Conyza (horseweed) and Ambrosia (ragweed) genera in the Asteraceae family was shown to be more susceptible to glyphosate resistance. Similarly, Amaranthus palmeri (Palmer amaranth), A. tuberculatus (roughfruit amaranth), A. hybridus (smooth pigweed), and A. spinosus (spiny pigweed) species were more prone to glyphosate resistance in the Amaranthaceae family. In the Chenopodiaceae family, the glyphosate-resistant was most prevalent in species Kochia scoparia (Mexican fireweed) and Salsola tragus (prickly Russian thistle) (Heap and Duke, 2018).

The continued exposure to glyphosate has been shown to develop resistance to glyphosate in several weed species including Buckhorn Plantain (Plantago lanceolate), Common Ragweed (Ambrosia artemisiifolia), Common Waterhemp (Amaranthus tuberculatus), Giant Ragweed (Ambrosia trifida), Goose-grass (Eleusine indica), Hairy Fleabane (Conyza bonariensis), Horseweed (Erigeron canadensis), Italian Ryegrass (Lolium multiflorum), Johnson-grass (Sorghum halepense), Jungle Rice (Echinochloa colona), Mexican fireweed (Kochia scoparia), Liverseed Grass (Urochloa panicoides), Palmer Amaranth (Amaranthus palmeri), Ragweed Parthenium (Parthenium hysterophorus), Rigid Ryegrass (Lolium rigidum), Sour-grass (Digitaria insularis), Sumatran Fleabane (Conyza sumatrensis), and Wild Poinsettia (Euphorbia heterophylla) (Nandula et al., 2005).

The mechanism of resistance to glyphosate includes (i) Target site resistance (single or multiple base pair alteration, gene amplification or duplication) and (ii) Non-Target 
site resistance (enhanced metabolism, decreased absorption and translocation, sequestration) (Nandula et al., 2017; Heap and Duke, 2018). Dose-dependent development of glyphosate resistance in weeds was also reported. Where, the higher dose was shown to eliminate susceptible populations, resulting in rapid evolution of herbicide resistance in weeds (Heap and Duke, 2018), while, low herbicide dose permits the possibility for outcrossing, cross pollution, and combining in weed populations, which gains glyphosate resistance traits to endure higher glyphosate rates (creeping resistance) (Gressel, 2009; Sammons and Gaines, 2014). The higher level of 3-deoxy-d-arbino-heptulosonate 7-phosphate synthase, involved in the shikimate pathway, is also proposed to be responsible for enhanced carbon flow, which further assisted is imparting the glyphosate resistance (Pline-Srnic, 2006). The over expression of EPSPS gene was reported to be the primary mechanism involved in resistance development to glyphosate herbicide in L. perenne (Tani et al., 2016; Yanniccari et al., 2017). Target-site mutations related reduced translocation of glyphosate was reported in beggarticks (Bidens Pilosa) (Alcantara-de la Cruz et al., 2016a). Similarly, reduced uptake and translocation in rigid ryegrass ( $L$. rigidum) (Fernandez-Moreno et al., 2017b), reduced absorption and translocation in tropical sprangletop (Lepthochloa virgate) (Alcántara-de la Cruz et al., 2016b), target-site mutations in L. perenne populations (Karn and Jaseniuk, 2017), and target-site and non-target-site resistance in congress grass (Parthenium hysterophorus) (Bracamonte et al., 2016) was implicated in resistance development.

\section{Plant physiology and phytotoxicity}

In plants, glyphosate usage blocks the synthesis of the aromatic amino acids such as phenylalanine, tyrosine, and tryptophan by targeting the enzyme EPSPS of the shikimic acid pathway. Application of Roundup ${ }^{\circledR}$ to cotton was reported to affect boll distribution and cause abnormality of bolls, which reduces cotton yield, fiber quality, ginning percentage (Viator et al., 2000). Glyphosate application in GR-cotton was shown to reduce plant reproductive attributes such as modifications in floral morphology, pollen viability, and pollination efficiency leading to poor seed setting and greater boll loss (Pline et al., 2003). Glyphosate exposures to crop plants were also reported to alter the characteristics of root exudates, quantitatively and qualitatively affecting their functional roles. In GR-soybean, while the carbohydrates characteristics were not affected by glyphosate application, the amino acids exudation was found to get increased (Kremer et al., 2005).

Hormesis (a stimulatory effect of toxin/herbicide/chemicals on plant growth) is a phenomenon stimulated by the lower concentrations of several herbicides on crop plants. However, sub-toxic concentrations of glyphosate brought a significant change in a plant population of the same species, affecting their growth and development (Brito et al., 2018). Similarly, lower concentrations of glyphosate leaching and runoff from the land to water bodies also stimulate the growth of some algae via hormesis causing eutrophication, however, the glyphosate induced hormesis in algae is generally less (Dabney and Patiño, 2018).

In weed management, application of the recommended rates of glyphosate was not found to affect the mineral composition of GR crops (Duke et al., 2018; Reddy et al., 2018). However, charged minerals such as aluminum and iron oxides act as a binding site for glyphosate in most of the soils (Borggaard and Gimsing, 2008). Glyphosate also 
competes for adsorption sites in soil along with phosphate ions, indicating the significant role of phosphate fertilizers in glyphosate remobilization in soils (Bott et al., 2008). Soils without enough binding sites (example sandy soils) for glyphosate residues cause phytotoxicity due to the presence of unbound glyphosate (Cornish, 1992). Since the glyphosate is an anion at physiological $\mathrm{pH}$, it binds well with most of the divalent metal cations, thus reducing the possibility of phytotoxicity. However, chelating characteristics of glyphosate were linked to phytotoxicity and negative effects on other organisms (Mertens et al., 2018).

\section{Plant defense mechanisms and disease tolerance}

Glyphosate herbicide usage in crop plants is implicated in the susceptibility of plants to several diseases through inhibition of EPSPS, which disrupts the shikimic acid pathway, and shikimic acid pathway-derived compounds (phenolics, defense molecules, lignin derivatives, salicylic acid, anthranilic acid, phytoalexins and lignans), that plant syntheses to protect themselves from microbial plant pathogens (Hammerschmidt, 2018). In nutritional aspects, the application of glyphosate was reported to impact plant uptake and transport of micronutrients $(\mathrm{Mn}, \mathrm{Fe}, \mathrm{Cu}$, and $\mathrm{Zn}$ ), whose shortage can reduce plant growth and disease resistance (Johal and Huber, 2009). The root infection caused by Fusarium spp. in GR-soybean cultivars were found to get aggravated by glyphosate application under controlled and field conditions (Kremer and Means, 2009). Further, glyphosate application also decreased Pseudomonas spp, IAA-producing bacteria, and ratio of manganese-reducing to manganese-microbial populations (Kremer and Means, 2009). Glyphosate usage and GR were also linked to sudden death syndrome, in soybean caused by Fusarium virguliforme (Njiti et al., 2003).

Though the quantum of glyphosate required to destroy the weeds is considerably low in the presence of plant pathogens (Duke et al., 2018), glyphosate application can be toxic to microbes, particularly rusts (Feng et al., 2005). The drift of glyphosate from sprayed fields be phytotoxic and can decrease the defense mechanism of non-GR plants to plant pathogens (Hammerschmidt, 2018). Glyphosate application to GR soybean was reported not to increase its susceptibility to Sclerotinia sclerotiorum (Nelson et al., 2002). Similarly, there were inadequate data to establish a relationship between glyphosate usage and plant diseases caused by Fusarium spp (Powell and Swanton, 2008).

\section{Non-target vegetation}

Glyphosate is one of the most important herbicides used worldwide on non-GR croplands. Leaching, runoff, and drifting of spray droplets from the treated area are the primary source of glyphosate exposure to non-target vegetations (Duke, 2020). The glyphosate required to cause phytotoxicity in plant species varies considerably depending upon the plant type, glyphosate concentration and its drift levels (Duke, 2020). Glyphosate is documented to have a shorter half-life and low drift potential compared to other herbicides, indicating its safeness on non-target vegetation (Heap and Duke, 2018). Further, the low vapour pressure properties of the glyphosate acid and the isopropylamine salt of glyphosate make them virtually nonvolatile (Duke, 2020). Commonly, the glyphosate that drifts and settling on plant surfaces are either used by the plants as a nutrient source or reaches the soil through rain (Duke, 2020). There 
found to be a minimal plant injury even with aerial spray of glyphosate at minimal distances (Cederlund, 2017). Around 21\% of glyphosate and $42 \%$ of AMPA was recorded in European surface-soils, where the GR crops were not grown, indicating the drift potential of glyphosate on non-targeted vegetations (Silva et al., 2018). The impact of glyphosate application on non-target plant species has been studied in several crops including peas (Pisum sativum) (Orcaray et al., 2012; Zabalza et al., 2017), rice (Oryza sativa) (Ahsan et al., 2008), soybean (Glycine max) (Hernandez et al., 1999), etc. In most occurrences, glyphosate application was reported to influence the photosynthetic rate and chlorophyll biosynthesis (Zobiole et al., 2012; Serra et al., 2013), photochemical reactions (Vivancos et al., 2011), carbon and nitrogen metabolism (Zobiole et al., 2010; Ding et al., 2011), plant mineral uptake (Cakmak et al., 2009; Zobiole et al., 2010, 2011, 2012), phytohormone synthesis (Sergiev et al., 2006; Miteva et al., 2010), fatty acids and amino acids synthesis (Gomes et al., 2017), secondary metabolite synthesis (Yanniccari et al., 2012). The GBH application also influences the activity of enzymes such as ascorbate peroxidase, catalase, and polyamines (Mkandawire et al., 2014).

\section{Soil microorganisms and their diversity}

Glyphosate affect soil microorganisms, their community composition (Kremer and Means, 2009) and their ecological functions, however, most of those effects are found to be minor and transient in nature (Nguyen et al., 2016). Soil microorganisms are capable of using glyphosate as carbon and phosphorus sources (Eser et al., 2007). The effects of glyphosate be transient and minimal on soil microbial population and their functions, as there is no report on yield reductions in GR-crops (Duke and Reddy, 2018). Based on the FAME analysis, glyphosate application to GR-soybean under field conditions had no effect on the rhizosphere and bulk soil community composition (Weaver et al., 2007). Glyphosate usage in GR-corn was shown not to affect the denitrifying bacteria and fungal populations compared with GR-corn and glyphosate sensitive (GS) corn isoline treated with conventional herbicides (Hart et al., 2009). Glyphosate application does not have a significant effect on cotton rhizosphere microbial community composition and their function (Barriuso and Mellado, 2012). There found to no negative effect on root colonization efficiency of Arbuscular mycorrhizal fungi in GR-cotton, corn, and soybean (Savin et al., 2009). However, nitrogen + glyphosate application was reported to negatively affect the growth of AMF as well as the dehydrogenase activity in the silt loam soil (Nivelle et al., 2018). Similarly, the fungal:bacterial ratios were unaffected by glyphosate applications to GRsoybeans (Lane et al., 2012). Pyrosequencing of cloned 16S-rDNA from GR-corn rhizosphere showed no variations in microbial community composition compared to the glyphosate or GTZ (acetochlor + terbuthylazine) treatment (Barriuso et al., 2010). Similarly, long-term studies identified three dominant microbial groups (Proteobacteria, Actinobacteria, and Acidobacteria) in the GR-corn rhizosphere, which indicated a nil or transient effect of glyphosate on these communities (Barriuso et al., 2011). Long-term usage of glyphosate in glyphosate tolerant cropping, resulted in shifts in subpopulations of soil rhizosphere-associated bacterial communities (Xanthamonadales, Acidobacteria), and bacterial exposure to glyphosate was shown to affect their community composition (increased proliferation of glyphosate tolerant bacteria) and down-regulation of carbon metabolism (Newman et al., 2016). 
Glyphosate have direct toxicity on some bacteria, fungi, and protists as these organisms also use the shikimic acid pathway (Feng et al., 2005). Even, mycorrhizal fungi were reported to be sensitive to glyphosate exposure, which affects root colonization efficiency and spore viability (Druille et al., 2013). Higher concentrations of glyphosate inhibit nitrogen fixing potential of cyanobacteria (Bodkhe and Tarar, 2016). The reduction in nodulation efficiency, nitrogen fixation and biomass buildup was reported in GR-soybeans subjected for glyphosate treatment (Zablotowicz and Reddy, 2004). Glyphosate application to GR-soybeans reported to affect leaf chlorophyll, root biomass, plant nitrogen content, nodule biomass and nitrogenase activity compared to the untreated control. However, there are no significant differences between treated and control plants on nifH gene abundance (Fan et al., 2017). The combined application of nitrogenous fertilizers and glyphosate does not affect the activities of either ammonia-oxidizing bacteria or archaea and their nitrification activities (Zabaloy et al., 2017). Though the glyphosate application was found to be harmful to microbial populations up to 30 days, the population recovered after 60 days and reached the original level in acidic soil (Kumar et al., 2017) and lateritic soil (Shitha, 2014). The application of higher doses of glyphosate in glyphosate sensitive (GS) pea and triticale was reported to increase the ammonia concentrations in the rhizosphere soil, thus affecting microbial community diversity and richness compared to the control treatments (Mijangos et al., 2009).

\section{Insects and aquatic life}

Evidence suggests that GBHs can have an adverse effect on aquatic invertebrate ecology, including amphibian larvae (Cuhra et al., 2013). Simultaneous exposure to GBHs and other stressors has been shown to increase undesirable impacts on fish and amphibians (Jones et al., 2011). Glyphosate concentrations of over $400 \mu \mathrm{g} \mathrm{L}^{-1}$ are possibly toxic to some aquatic species including amphibians and fish (Annette et al., 2014; Braz-Mota et al., 2015). The occurrence of glyphosate in marine ecosystems and its persistence in sea water is also reported (Mercurio et al., 2015). GBHs have negative (phytoplankton and nitrifying community) as well as positive (cyanobacteria) impact on aquatic microorganisms (Vera et al., 2010). The impacts of glyphosate or GBHs can also have differential effects on arthropods, predators and parasites (European Commission, 2002). Honey bees exposure to glyphosate or GBHs at sub-lethal concentrations can impair their behaviour and cognitive capacities (Balbuena et al., 2015). Glyphosate usage in GR soybean and corn was reported to be responsible for the decline in monarch butterflies (Danaus plexippus L.) and milkweed (Asclepias spp.) population (Pleasants and Oberhauser, 2013). However, further studies established that the use of synthetic herbicides for weed management in those crops was responsible for the decline in the population of monarch butterflies, rather than the adoption of GRcrops (Boyle et al., 2019).

\section{Fauna and invertebrates}

Exposure to glyphosate has significant effects on earthworm activity and ecological functions, including a decrease in body weight, cocoons and juvenile's population (Gaupp-Berghausen et al., 2015; García-Pérez et al., 2016, 2020). The hatching percentage of Eisenia fetida (red wiggler) cocoons was also reported to get reduced 
significantly on exposure to soils treated with Roundup herbicide (Verrell and Van Buskirk, 2004). Glyphosate application also affected the survival rate and cocoon production in Lumbricus terrestris (night crawler), Octodrilus complanatusas (large earthworm), and Aporrectodea caliginosa (grey worm) (Stellin et al., 2018). Though earthworms showed glyphosate (1.2 and $\left.2.4 \mathrm{a} . \mathrm{i} \mathrm{kg} \mathrm{ha}{ }^{-1}\right)$ avoidance, multiplication of earthworms was not affected by glyphosate exposure (Shitha, 2014). Based on litter decomposition studies on GR-soybean and near isoline-sensitive cultivars, protists and nematode populations were not affected by GR-soybean (Powell et al., 2009). Application of GBHs, Roundup, was reported to show a transient effect on the population and functioning of soil fauna enchytraeids and nematodes (Hagner et al., 2019).

\section{Conclusions and future outlook}

Since its introduction in 1974, the usage of glyphosate and GBHs has increased approximately 100-fold. Though glyphosate and GBHs affect human and animal health initially, subsequent clinical studies and critical analyses by regulatory bodies concluded that glyphosate is unlikely to cause health risk in humans. However, several world regulatory bodies still raise doubts on impact of glyphosate and GBHs to longterm exposure on human, animals, plants and other non-targets groups, and recommend having more data on its impact on the environment. Nevertheless, several studies have reported the fate of glyphosate in natural ecosystems related to its persistence, degradation and residual effects on crops, there is still a lack of knowledge on glyphosate and GBHs effects on soil, plant (nutrient mobilization, nutrient availability, plant nutrient uptake, phytotoxicity, plant defense, disease tolerance, microbial diversity, faunal activities, enzyme activities, etc.) and environmental quality subjected to its long-term exposure. Further the adoption of multi-cropping systems including intercrops becomes a big question on the event of adoption of HT crops, as the crops which are engineered to express cp4-epsps only can survive the glyphosate application. Due to indiscriminate use of glyphosate and GBHs in agricultural lands, there is likely chance to increase the emergence of glyphosate-resistant weeds (Super weeds). However, the available literature infers the ecological effects of glyphosate and GBHs are posing low risk to the environment and the effects are transient. While several studies have reported the negative impact of glyphosate and GBHs on soil, plant, and environmental health, a few also reported the positive effects of glyphosate and GBHs on reduction of greenhouse gas emissions, a decline in the use of fossil fuel in agriculture, enhancement in carbon sequestration, soil conservation, plant growth stimulatory effects, increased yield, reduction in the cost of cultivation, and lesser competition for agricultural lands.

To conclude, though there were extensive studies on the positive and negative impact of glyphosate and GBHs on the environment, the following are the points for consideration with regard to future environmental management with regard to glyphosate usage:

a) Impact on natural enemies of crop plants in different agroecosystems.

b) Impact on natural plant innate defense system against biotic and abiotic stresses.

c) Soil-water-plant relationships, nutrient recycling, nutrient availability and plant uptake under different agro-ecological conditions. 
d) Soil biology and alteration in food-webs including micro, meso, and macro-flora and fauna diversity.

e) Long-term exposure on beneficial microorganisms and their ecological functions.

f) Soil and ground water contamination, biomagnification, entry to the food supply chain in important staple and commercial crops.

g) Impact on fresh and marine ecosystems, biogeochemistry, and nutrient sequestration.

h) Long-term exposure studies on mammals including humans and their risk assessment.

i) Glyphosate residues in crop wastes, its persistence, and their impacts on recycling and agricultural use.

j) Horizontal gene transfer in non-targeted vegetations with regard to use of glyphosate resistant crops.

Conflict of interests. The authors have no conflict of interests.

\section{REFERENCES}

[1] Acquavella, J., Alexander, B., Mandel, J., Gustin, C., Baker, B., Chapman, P., Bleeke, M. (2004): Glyphosate biomonitoring for farmers and their families: Results from the farm family exposure study. - Environ Health Perspectives 112(3): 321-326.

[2] Ahsan, N., Lee, D. G., Lee, K. W., Alam, I., Lee, S. H., Bahk, J. D., Lee, B. H. (2008): Glyphosate-induced oxidative stress in rice leaves revealed by proteomic approach. Plant Physiology and Biochemistry 46: 1062-1070.

[3] Alcántara-de la Cruz, R., Fernández-Moreno, P. T., Ozuna, C. V., Rojano-Delgado, A. M., Cruz-Hipolito, H. E., Domínguez-Valenzuela, J. A., Barro, F., De Prado, R. (2016a): Target and non-target site mechanisms developed by glyphosate-resistant Hairy beggarticks (Bidens pilosa L.) populations from Mexico. - Frontiers in Plant Science 7: 1492.

[4] Alcántara-de la Cruz, R., Rojano-Delgado, A. M., Giménez, M. J., Cruz-Hipolito, H. E., Domínguez-Valenzuela, J. A., Barro, F., De Prado, R. (2016b): First resistance mechanisms characterization in glyphosate-resistant Leptochloa virgata. - Frontiers in Plant Science 7: 1742.

[5] Alexa, E., Sumalan, R., Negrea, M., Bragea, M., Poiana, M. A., Radulov, I., Lazureanu, A. (2010): Studies on the biodegradation capacity of 14C-labelled glyphosate in vine plantation soils. - Journal of Food, Agriculture and Environment 8(3-4 Part 2): 11931198.

[6] Andert, S., Mutz, J. E., Wiese, A., de Mol, F., Steinmann, H. H., Gerowitt, B. (2019): Farmers' statements are reliable - Comparing two different data sources about glyphosate use in Germany. - Crop Protection 124: 104876.

[7] Annett, R., Habibi, H. R., Hontela, A. (2014): Impact of glyphosate and glyphosate-based herbicides on the freshwater environment. - Journal of Applied Toxicology 34: 458-479.

[8] Arregui, M. C., Lenardon, A., Sanchez, D., Maitre, M. I., Scotta, R., Enrique, S. (2004): Monitoring glyphosate residues in transgenic glyphosate-resistant soybean. - Pest Management Science 60: 163-166.

[9] Bai, S. H., Ogbourne, S. M. (2016): Glyphosate: Environmental contamination, toxicity and potential risks to human health via food contamination. - Environmental Science and Pollution Research 23: 18988-19001.

[10] Bailey, D. C., Todt, C. E., Burchfield, S. L., Pressley, A. S., Denney, R. D., Snapp, I. B., Negga, R., Traynor, W. L., Fitsanakis, V. A. (2017): Chronic exposure to a glyphosate- 
containing pesticide leads to mitochondrial dysfunction and increased reactive oxygen species production in Caenorhabditis elegans. - Environmental Toxicology and Pharmacology 57: 46-52.

[11] Balbuena, M. S., Tison, L., Hahn, M. L., Greggers, U., Menzel, R., Farina, W. M. (2015): Effects of sublethal doses of glyphosate on honeybee navigation. - Journal of Experimental Biology 218(17): 2799-2805.

[12] Balmford, A., Amano, T., Bartlett, H., Chadwick, D., Collins, A., Edwards, D. (2018): The environmental costs and benefits of high-yield farming. - Nature Sustainability 1(9): 477-485.

[13] Barfoot, P., Brookes, G. (2014): Key global environmental impacts of genetically modified (GM) crop use 1996-2012. - GM crops \& food 5(2): 149-160.

[14] Barriuso, J., Marín, S., Mellado, R. P. (2010): Effect of the herbicide glyphosate on glyphosate-tolerant maize rhizobacterial communities: A comparison with pre-emergency applied herbicide consisting of a combination of acetochlor and terbuthylazine. Environmental Microbiology 12(4): 1021-1030.

[15] Barriuso, J., Marín, S., Mellado, R. P. (2011): Potential accumulative effect of the herbicide glyphosate on glyphosate-tolerant maize rhizobacterial communities over a three-year cultivation period. - PLoS ONE 6(11): e27558.

[16] Barriuso, J., Mellado, R. P. (2012): Glyphosate affects the rhizobacterial communities in glyphosate-tolerant cotton. - Applied Soil Ecology 5: 20-26.

[17] Battaglin, W. A., Meyer, M. T., Kuivila, K. M., Dietze, J. E. (2014): Glyphosate and its degradation product AMPA occur frequently and widely in U.S. soils, surface water, groundwater, and precipitation. - Journal of the American Water Resources Association 50(2): 275-290.

[18] Benbrook, C. M. (2012): Impacts of genetically engineered crops on pesticide use in the U.S.-the first sixteen years. - Environmental Sciences Europe 24: 24.

[19] Bodkhe, S. S., Tarar, J. L. (2016): Impact of herbicide Glyphosate on metabolic activities of Cyanobacterial species. - Phykos 46(1): 1-6.

[20] Bøhn, T., Cuhra, M., Traavik, T., Sanden, M., Fagan, J., Primicerio, R. (2014): Compositional differences in soybeans on the market: Glyphosate accumulates in Roundup Ready GM soybeans. - Food Chemistry 153: 207-215.

[21] Borggaard, O. K., Gimsing, A. L. (2008): Fate of glyphosate in soil and the possibility of leaching to ground and surface waters: A review. - Pest Management Science 64(4): 441456.

[22] Bott, S., Tesfamariam, T., Candan, H., Cakmak, I., Römheld, V., Neumann, G. (2008): Glyphosate-induced impairment of plant growth and micronutrient status in glyphosateresistant soybean (Glycine max L.). - Plant and Soil 312(1-2): 185-194.

[23] Botta, F., Lavison, G., Couturier, G., Alliot, F., Moreau-Guigon, E., Fauchon, N., Guery, B., Chevreuil, M., Blanchoud, H. (2009): Transfer of glyphosate and its degradate AMPA to surface waters through urban sewerage systems. - Chemosphere 77(1): 133-139.

[24] Boyle, J. H., Dalgleish, H. J., Puzey, J. R. (2019): Monarch butterfly and milkweed declines substantially predate the use of genetically modified crops. - Proceedings of the National Academy of Sciences of the United States of America 116(8): 3006-3011.

[25] Bracamonte, E., Fernández-Moreno, P. T., Barro, F., De Prado, R. (2016): Glyphosateresistant Parthenium hysterophorus in the Caribbean Islands: Non Target Site resistance and target site resistance in relation to resistance levels. - Frontiers in Plant Science 7: 1845.

[26] Bracamonte, E. R., Fernández-Moreno, P. T., Bastida, F., Osuna, M. D., Alcántara-de la Cruz, R., Cruz-Hipolito, H. E., De Prado, R. (2017): Identifying Chloris species from Cuban citrus orchards and determining their glyphosate-resistance status. - Frontiers in Plant Science 8: 1977.

[27] Braz-Mota, S., Sadauskas-Henrique, H., Duarte, R. M., Val, A. L., Almeida-Val, V. M. (2015): Roundup ${ }^{\circledR}$ exposure promotes gills and liver impairments, DNA damage and 
inhibition of brain cholinergic activity in the Amazon teleost fish Colossoma macropomum. - Chemosphere 135: 53-60.

[28] Brito, I. P. F. S., Tropaldi, L., Carbonari, C. A., Velini, E. D. (2018): Hormetic effects of glyphosate on plants. - Pest Management Science 74(5): 1064-1070.

[29] Brookes, G., Taheripour, F., Tyner, W. E. (2017): The contribution of glyphosate to agriculture and potential impact of restrictions on use at the global level. - GM Crops and Food 8(4): 216-228.

[30] Brookes, G. (2018): Glyphosate use in Asia and implications of possible restrictions on its use. - AgBioForum 21(2): 1-26.

[31] Brookes, G., Barfoot, P. (2018): Environmental impacts of genetically modified (GM) crop use 1996-2016: Impacts on pesticide use and carbon emissions. - GM Crops and Food 9(3): 109-139.

[32] Busse, M. D., Ratcliff, A. W., Shestak, C. J., Powers, R. F. (2001): Glyphosate toxicity and the effects of long-term vegetation control on soil microbial communities. - Soil Biology and Biochemistry 33(12-13): 1777-1789.

[33] Cakmak, I., Yazici, A., Tutus, Y., Ozturk, L. (2009): Glyphosate reduced seed and leaf concentrations of calcium, manganese, magnesium, and iron in non-glyphosate resistant soybean. - European Journal of Agronomy 31: 114-119.

[34] Cederlund, H. (2017): Effects of spray drift of glyphosate on nontarget terrestrial plants A critical review. - Environmental Toxicology and Chemistry 36(11): 2879-2886.

[35] Cerdeira, A. L., Duke, S. O. (2006): The current status and environmental impacts of glyphosate-resistant crops: a review. - Journal of Environmental Quality 35: 1633-1658.

[36] Cornish, P. S. (1992): Glyphosate residues in a sandy soil affect tomato transplants. Australian Journal of Experimental Agriculture 32(3): 395-399.

[37] Corvino, V. (2015): StopGlifosato, le 10 Misure Alternative All'erbicida. Il Salvagente. Available online: https: //ilsalvagente.it/2015/08/07/stopglifosato-le-10-misurealternative-allerbicida/ (accessed on 03 July 2021).

[38] Cuhra, M., Traavik, T., Bøhn, T. (2013): Clone- and age-dependent toxicity of a glyphosate commercial formulation and its active ingredient in Daphnia magna. Ecotoxicology 22(2): 251-262.

[39] Cuhra, M., Bøhn, T., Cuhra, P. (2016): Glyphosate: Too much of a good thing? Frontiers in Environmental Science 4: 28.

[40] Dabney, B. L., Patiño, R. (2018): Low-dose stimulation of growth of the harmful alga, Prymnesium parvum, by glyphosate and glyphosate-based herbicides. - Harmful Algae 80: 130-139.

[41] Ding, W., Reddy, K. N., Zablotowicz, R. M., Bellaloui, N., Bruns, H. A. (2011): Physiological responses of glyphosate-resistant and glyphosate-sensitive soybean to aminomethylphosphonic acid, a metabolite of glyphosate. - Chemosphere 83: 593-598.

[42] Druille, M., Omacini, M., Golluscio, R. A., Cabello, M. N. (2013): Arbuscular mycorrhizal fungi are directly and indirectly affected by glyphosate application. Applied Soil Ecology 72: 143-149.

[43] Duke, S. O., Rimando, A. M., Pace, P. F., Reddy, K. N., Smeda, R. J. (2003): Isoflavone, glyphosate, and aminomethylphosphonic acid levels in seeds of glyphosate-treated, glyphosate-resistant soybean. - Journal of Agricultural and Food Chemistry 51: 340-344.

[44] Duke, S. O. (2005): Taking stock of herbicide-resistant crops ten years after introduction. - Pest Management Science 61(3): 211-218.

[45] Duke, S., Powles, S. (2008): Glyphosate: a once in a century herbicide. - Pest management science 325: 319-325.

[46] Duke, S. O., Powles, S. B. (2009): Glyphosate-resistant crops and weeds: Now and in the future. - AgBioForum 12(3-4): 346-357.

[47] Duke, S. O. (2011): Glyphosate degradation in glyphosate-resistant and -susceptible crops and weeds. - Journal of Agricultural and Food Chemistry 59(11): 5835-5841. 
[48] Duke, S. O. (2018): The history and current status of glyphosate. - Pest Management Science 74(5): 1027-1034.

[49] Duke, S. O., Reddy, K. N. (2018): Is mineral nutrition of glyphosate-resistant crops altered by glyphosate treatment? - Outlooks on Pest Management 29(5): 206-208.

[50] Duke, S. O., Rimando, A. M., Reddy, K. N., Cizdziel, J. V., Bellaloui, N., Shaw, D. R., Williams $2^{\text {nd }}$, M. M., Maul, J. E. (2018): Lack of transgene and glyphosate effects on yield, and mineral and amino acid content of glyphosate-resistant soybean. - Pest Management Science 74(5): 1166-1173.

[51] Duke, S. O. (2020): Glyphosate: Environmental fate and impact. - Weed Science 68(3): 201-207.

[52] EcoWatch: Available online: https://www.ecowatch.com/85-of-tampons-containmonsantos-cancer-causing-glyphosate-1882112780.html (accessed on 03 July 2021).

[53] Eser, F., Aka Sağliker, H., Darici, C. (2007): The effects of glyphosate isopropylamine and trifluralin on the carbon mineralization of olive tree soils. - Turkish Journal of Agriculture and Forestry 31(5): 297-302.

[54] European Commission (EU). (2002): European Commission Health \& Consumer Protection Directorate-General. Directorate E-Food Safety: plant health, animal health and welfare, international questions. E1 Plant Health. - Review report for the active substance glyphosate, Glyphosate 6511/IV/99-final, 21. January 2002, Brüssel. http:// ec.europa.eu /food /plant/ pesticides/eu-pesticides-database/public/? event= active substance. View Review\&id=87. (accessed on 07 September 2020).

[55] European Food Safety Authority (EFSA): Available online: https://www.efsa.europa.eu /en /topics/topic/glyphosate (accessed on 1 June 2021).

[56] European Food Safety Authority (EFSA). (2015): Conclusion on the peer review of the pesticide risk assessment of the active substance glyphosate. - EFSA Journal 13: 4302.

[57] European Food Safety Authority (EFSA). (2017): Peer review of the pesticide risk assessment of the potential endocrine disrupting properties of glyphosate. - EFSA Journal 15(9): 4979.

[58] Fan, L., Feng, Y., Weaver, D. B., Delaney, D. P., Wehtje, G. R., Wang, G. (2017): Glyphosate effects on symbiotic nitrogen fixation in glyphosate-resistant soybean. Applied Soil Ecology 121: 11-19.

[59] Feng, P. C. C., Baley, G. J., Clinton, W. P., Bunkers, G. J., Alibhai, M. F., Paulitz, T. C., Kidwell, K. K. (2005): Glyphosate inhibits rust diseases in glyphosate-resistant wheat and soybean. - Proceedings of the National Academy of Sciences of the United States of America 102(48): 17290-17295.

[60] Fernández-Moreno, P. T., Alcántara-de la Cruz, R., Smeda, R. J., De Prado, R. (2017a): Differential resistance mechanisms to glyphosate result in fitness cost for Lolium perenne and L. multiflorum. - Frontiers in Plant Science 8: 1796.

[61] Fernández-Moreno, P. T., Bastida, F., De Prado, R. (2017b): Evidence, mechanism and alternative chemical seedbank-level control of glyphosate resistance of a Rigid Ryegrass (Lolium rigidum) Biotype from Southern Spain. - Frontiers in Plant Science 8: 450.

[62] Food and Agriculture Organization (FAO). (2016): Pesticides residues in food. - Paper 231-Part I and Part II, FAO of United Nations: Rome, Italy.

[63] Foods Navigator: Available online: https://www.foodnavigator.com/Article/2016/03/14/ Almost-all-Germans-contaminated-with-glyphosate-warns-study (accessed on 03 July 2021).

[64] García-Pérez, J. A., Alarcón, E., Hernández, Y., Hernández, C. (2016): Impact of litter contaminated with glyphosate-based herbicide on the performance of Pontoscolex corethrurus, soil phosphatase activities and soil pH. - Applied Soil Ecology 104: 31-41.

[65] García-Pérez, J. A., Alarcón-Gutiérrez, E., Díaz-Fleischer, F. (2020): Interactive effect of glyphosate-based herbicides and organic soil layer thickness on growth and reproduction of the tropical earthworm Pontoscolex corethrurus (Müller, 1857). - Applied Soil Ecology 155: 103648. 
[66] Gardner, J. G., Nelson, G. C. (2008): Herbicides, glyphosate resistance and acute mammalian toxicity: Simulating an environmental effect of glyphosate-resistant weeds in the USA. - Pest Management Science 64(4): 470-478.

[67] Gaupp-Berghausen, M., Hofer, M., Rewald, B., Zaller, J. G. (2015): Glyphosate-based herbicides reduce the activity and reproduction of earthworms and lead to increased soil nutrient concentrations. - Scientific Reports 5: 12886.

[68] Gerritse, R. G., Beltran, J., Hernandez, F. (1996): Adsorption of atrazine, simazine, and glyphosate in soils of the Gnangara Mound, Western Australia. - Australian Journal of Soil Research 34(4): 599-607.

[69] Gillezeau, C., van Gerwen, M., Shaffer, R. M., Rana, I., Zhang, L., Sheppard, L., Taioli, E. (2019): The evidence of human exposure to glyphosate: a review. - Environmental Health 18: 2.

[70] Givens, W. A., Shaw, D. R., Kruger, G. R., Johnson, W. G., Weller, S. C., Young, B. G., Wilson, R. G., Owen, M. D. K., Jordan, D. (2009): Survey of tillage trends following the adoption of Glyphosate-Resistant crops. - Weed Technology 23(1): 150-155.

[71] Glass, R. L. (1984): Metal complex formation by glyphosate. - Journal of Agricultural and Food Chemistry 32: 1249-1253.

[72] Gomes, M. P., Le Manac'h, S. G., Hénault-Ethier, L., Labrecque, M., Lucotte, M., Juneau, P. (2017): Glyphosate-dependent inhibition of photosynthesis in willow. Frontiers in Plant Science 8: 207.

[73] Gonzalez-Torralva, F., Gil-Humanes, J., Barro, F., Brants, I., de Prado, R. (2012): Target site mutation and reduced translocation are present in a glyphosate-resistant Lolium multiflorum Lam. biotype from Spain. - Plant Physiology and Biochemistry 58: 16-22.

[74] Gressel, J. (2009): Evolving understanding of the evolution of herbicide resistance. - Pest Management Science 65(11): 1164-1173.

[75] Hagner, M., Mikola, J., Saloniemi, I., Saikkonen, K., Helander, M. (2019): Effects of a glyphosate-based herbicide on soil animal trophic groups and associated ecosystem functioning in a northern agricultural field. - Scientific Reports 9: 8540.

[76] Hammerschmidt, R. (2018): How glyphosate affects plant disease development: it is more than enhanced susceptibility. - Pest Management Science 74(5): 1054-1063.

[77] Hart, M. M., Powell, J. R., Gulden, R. H., Dunfield, K. E., Peter Pauls, K., Swanton, C. J., Klironomos, J. N., Antunes, P. M., Koch, A. M., Trevors, J. T. (2009): Separating the effect of crop from herbicide on soil microbial communities in glyphosate-resistant corn. - Pedobiologia 52(4): 253-262.

[78] Heap, I., Duke, S. O. (2018): Overview of glyphosate-resistant weeds worldwide. - Pest Management Science 74(5): 1040-1049.

[79] Heap, I. (2020): The International Survey of Herbicide Resistant Weeds. - Available online at: www.weedscience.org (Accessed on June 04, 2021).

[80] Hernandez, A., Garcia-Plazaola, J. I., Becerril, J. M. (1999): Glyphosate effects on phenolic metabolism of nodulated soybean (Glycine max L. Merr.). - Journal of Agricultural and Food Chemistry 47: 2920-2925.

[81] Imparato, V., Santos, S. S., Johansen, A., Geisen, S., Winding, A. (2016): Stimulation of bacteria and protists in rhizosphere of glyphosate-treated barley. - Applied Soil Ecology 98: 47-55.

[82] International Agency for Research on Cancer (IARC). (2015): IARC Monographs Vol. 112: Evaluation of five organophosphate insecticides and herbicides. - Available online: www.iarc.fr/en/media-centre/ iarcnews/pdf/MonographVolume112.pdf (Accessed on 03 July 2021).

[83] James, C. (2003): Global review of commercialized transgenic crops. - Current Science 84(3): 303-309.

[84] Jayasumana, C., Gunatilake, S., Senanayake, P. (2014): Glyphosate, hard water and nephrotoxic metals: Are they the culprits behind the epidemic of chronic kidney disease 
of unknown etiology in Sri Lanka? - Environmental Health: A Global Access Science Source Environmental Research and Public Health 11(2): 2125-2147.

[85] Jenkins, M. B., Locke, M. A., Reddy, K. N., McChesney, D. S., Steinriede, R. W. (2017): Impact of glyphosate-resistant corn, glyphosate applications and tillage on soil nutrient ratios, exoenzyme activities and nutrient acquisition ratios. - Pest Management Science 73(1): 78-86.

[86] Johal, G. S., Huber, D. M. (2009): Glyphosate effects on diseases of plants. - European Journal of Agronomy 31(3): 144-152.

[87] Jones, D. K., Hammond, J. I., Relyea, R. A. (2011): Competitive stress can make the herbicide Roundup ${ }^{\circledR}$ more deadly to larval amphibians. - Environmental Toxicology and Chemistry 30(2): 446-454.

[88] Karn, E., Jasieniuk, M. (2017): Nucleotide diversity at site 106 of EPSPS in Lolium perenne L. ssp. multiflorum from California indicates multiple evolutionary origins of herbicide resistance. - Frontiers in Plant Science 8: 777.

[89] Kaur, T., Walia, U. S. (2014): Bioefficacy of potassium salt of glyphosate in Bt cotton and its residual effect on succeeding crops. - Indian Journal of Weed Science 46(4): 358360 .

[90] Kier, L., Kirkland, D. (2013): Review of genotoxicity studies of glyphosate and glyphosate-based formulations. - Critical Reviews in Toxicology 43: 283-315.

[91] Kjaer, J., Olsen, P., Ullum, M., Grant, R. (2005): Leaching of Glyphosate and AminoMethylphosphonic Acid from Danish Agricultural Field Sites. - Journal of Environmental Quality 34(2): 608-620.

[92] Kniss, A. R. (2017): Long-term trends in the intensity and relative toxicity of herbicide use. - Nature Communications 8: 14865.

[93] Kremer, R. J., Means, N. E., Kim, S. (2005): Glyphosate affects soybean root exudation and rhizosphere micro-organisms. - International Journal of Environmental Analytical Chemistry 85(15): 1165-1174.

[94] Kremer, R. J., Means, N. E. (2009): Glyphosate and glyphosate-resistant crop interactions with rhizosphere microorganisms. - European Journal of Agronomy 31(3): 153-161.

[95] Krüger, M., Schrodl, W., Neuhaus, J., Shehata, A. A. (2013): Field investigations of glyphosate in urine of Danish dairy cows. - Journal of Environmental and Analytical Toxicology 3: 100186.

[96] Krüger, M., Schrödl, W., Pedersen, I., Shehata, A. A. (2014): Detection of glyphosate in malformed piglets. - Journal of Environmental and Analytical Toxicology 4: 1000230.

[97] Kumar, A., Ghosh, A., Mondal, D., Ghosh, R., Bandyopadhyay, P. (2017): Bio-efficacy of Ammonium Salt of Glyphosate 71\% SG for Weed Dynamics in Tea (Camellia sinensis L.) and its Effect on Soil Microflora. - International Journal of Current Microbiology and Applied Sciences 6(8): 2160-2170.

[98] Laitinen, P., Rämö, S., Siimes, K. (2007): Glyphosate translocation from plants to soil Does this constitute a significant proportion of residues in soil? - Plant and Soil 300(1-2): 51-60.

[99] Lancaster, S. H., Haney, R. L., Senseman, S. A., Kenerley, C. M., Hons, F. M. (2008): Microbial degradation of fluometuron is influenced by roundup weathermax. - Journal of Agricultural and Food Chemistry 56(18): 8588-8593.

[100] Lane, M., Lorenz, N., Saxena, J., Ramsier, C., Dick, R. P. (2012): Microbial activity, community structure and potassium dynamics in rhizosphere soil of soybean plants treated with glyphosate. - Pedobiologia 55(3): 153-159.

[101] Mamy, L., Barriuso, E., Gabrielle, B. (2016): Glyphosate fate in soils when arriving in plant residues. - Chemosphere 154: 425-433.

[102] Mensah, P. K., Muller, W. J., Palmer, C. G. (2012): Using growth measures in the freshwater shrimp Caridina nilotica as biomarkers of Roundup (R) pollution of South African freshwater systems. - Physics and Chemistry of the Earth 50-52: 262-268. 
[103] Mercurio, P., Flores, F., Mueller, J. F., Carter, S., Negri, A. P. (2015): Glyphosate persistence in seawater. - Marine Pollution Bulletin 85: 385-390.

[104] Mertens, M., Höss, S., Neumann, G., Afzal, J., Reichenbecher, W. (2018): Glyphosate, a chelating agent -relevant for ecological risk assessment? - Environmental Science and Pollution Research 25(6): 5298-5317.

[105] Mesnage, R., Defarge, N., Spiroux de Vendômois, J., Séralini, G. E. (2015): Potential toxic effects of glyphosate and its commercial formulations below regulatory limits. Food and Chemical Toxicology 84: 133-153.

[106] Mijangos, I., Becerril, J. M., Albizu, I., Epelde, L., Garbisu, C. (2009): Effects of glyphosate on rhizosphere soil microbial communities under two different plant compositions by cultivation-dependent and -independent methodologies. - Soil Biology and Biochemistry 41(3): 505-513.

[107] Miteva, L. P. E., Ivanov, S. V., Alexieva, V. S. (2010): Alterations in glutathione pool and some related enzymes in leaves and roots of pea plants treated with the herbicide glyphosate. - Russian Journal of Plant Physiology 57: 131-136.

[108] Mkandawire, M., Teixeira Da Silva, J. A., Dudel, E. G. (2014): The lemna bioassay: contemporary issues as the most standardized plant bioassay for aquatic ecotoxicology. Critical Reviews in Environmental Science and Technology 44: 154-197.

[109] Moms Across America. (2014): Available online: http://www.momsacrossamerica.com /glyphosate_testing_results (accessed on 03 July 2021).

[110] Myers, J. P., Antoniou, M. N., Blumberg, B., Carroll, L., Colborn, T., Everett, L. G., Hansen, M., Landrigan, P. J., Lanphear, B. P., Mesnage, R., Vandenberg, L. N., vom Saal, F. S., Welshons, W. V., Benbrook, C. M. (2016): Concerns over use of glyphosatebased herbicides and risks associated with exposures: A consensus statement. Environmental Health: A Global Access Science Source 15: 19.

[111] Nandula, V. K., Reddy, K. N., Duke, S. O., Poston, D. H. (2005): Glyphosate-resistant weeds: current status and future outlook. - Outlooks on Pest Management 16: 183.

[112] Nandula, V. K. (2010): Glyphosate Resistance in Crops and Weeds: History, Development, and Management. - John Wiley \& Sons: Hoboken, NJ, USA.

[113] Nandula, V. K., Tehranchian, P., Bond, J. A., Norsworthy, J. K., Eubank, T. W. (2017): Glyphosate resistance in common ragweed (Ambrosia artemisiifolia L.) from Mississippi, USA. - Weed Biology and Management 17: 45-53.

[114] Nelson, K. A., Renner, K. A., Hammerschmidt, R. (2002): Cultivar and herbicide selection affects soybean development and the incidence of Sclerotinia stem rot. Agronomy Journal 94(6): 1270-1281.

[115] Newman, M. M., Lorenz, N., Hoilett, N., Lee, N. R., Dick, R. P., Liles, M. R., Ramsier, C., Kloepper, J. W. (2016): Changes in rhizosphere bacterial gene expression following glyphosate treatment. - Science of the Total Environment 553: 32-41.

[116] Nguyen, D. B., Rose, M. T., Rose, T. J., Morris, S. G., van Zwieten, L. (2016): Impact of glyphosate on soil microbial biomass and respiration: A meta-analysis. - Soil Biology and Biochemistry 92: 50-57.

[117] Nguyen, N. K., Dörfler, U., Welzl, G., Munch, J. C., Schroll, R., Suhadolc, M. (2018): Large variation in glyphosate mineralization in 21 different agricultural soils explained by soil properties. - Science of the Total Environment 627: 544-552.

[118] Niemann, L., Sieke, C., Pfeil, R., Solecki, R. (2015): A critical review of glyphosate findings in human urine samples and comparison with the exposure of operators and consumers. - Journal of Consumer Protection and Food Safety 10: 3-12.

[119] Nivelle, E., Verzeaux, J., Chabot, A., Roger, D., Chesnais, Q., Ameline, A., Lacoux, J., Nava-Saucedo, J.-E., Tétu, T., Catterou, M. (2018): Effects of glyphosate application and nitrogen fertilization on the soil and the consequences on aboveground and belowground interactions. - Geoderma 311: 45-57. 
[120] Njiti, V. N., Myers, O., Schroeder, D., Lightfoot, D. A. (2003): Roundup Ready Soybean: Glyphosate effects on Fusarium solani root colonization and Sudden Death Syndrome. Agronomy Journal 95(5): 1140-1145.

[121] Okada, E., Costa, J. L., Bedmar, F. (2016): Adsorption and mobility of glyphosate in different soils under no-till and conventional tillage. - Geoderma 263: 78-85.

[122] Okada, E., Costa, J. L., Bedmar, F. (2019): Glyphosate dissipation in different soils under no-till and conventional tillage. - Pedosphere 29: 773-783.

[123] Orcaray, L., Zulet, A., Zabalza, A., Royuela, M. (2012): Impairment of carbon metabolism induced by the herbicide glyphosate. - Journal of Plant Physiology 169: 27 33.

[124] Peillex, C., Pelletier, M. (2020): The impact and toxicity of glyphosate and glyphosatebased herbicides on health and immunity. - Journal of Immunotoxicology 17: 163-174.

[125] Pleasants, J. M., Oberhauser, K. S. (2013): Milkweed loss in agricultural fields because of herbicide use: Effect on the monarch butterfly population. - Insect Conservation and Diversity 6(2): 135-144.

[126] Pline, W. A., Keith, L., Edmisten, J. W., Wells, W. R., Thomas, J. (2003): Glyphosateinduced reductions in pollen viability and seed set in glyphosate-resistant cotton and attempted remediation by gibberellic acid $\left(\mathrm{GA}_{3}\right)$. - Weed Science 51(1): 19-27.

[127] Pline-Srnic, W. (2006): Physiological mechanisms of glyphosate resistance. - Weed Technology 20: 290-300.

[128] Pollegioni, L., Schonbrunn, E., Siehl, D. (2011): Molecular basis of glyphosate resistance - Different approaches through protein engineering. - FEBS Journal 278(16): 2753-2766.

[129] Powell, J. R., Swanton, C. J. (2008): A critique of studies evaluating glyphosate effects on diseases associated with Fusarium spp. - Weed Research 48(4): 307-318.

[130] Powell, J. R., Levy-Booth, D. J., Gulden, R. H., Asbil, W. L., Campbell, R. G., Dunfield, K. E., Hamill, A. S., Hart, M. M., Lerat, S., Nurse, R. E., Peter Pauls, K., Sikkema, P. H., Swanton, C. J., Trevors, J. T., Klironomos, J. N. (2009): Effects of genetically modified, herbicide-tolerant crops and their management on soil food web properties and crop litter decomposition. - Journal of Applied Ecology 46(2): 388-396.

[131] Reddy, K. N., Cizdziel, J. V., Williams, M. M., Maul, J. E., Rimando, A. M., Duke, S. O. (2018): Glyphosate Resistance Technology Has Minimal or No Effect on Maize Mineral Content and Yield. - Journal of Agricultural and Food Chemistry 66(39): 10139-10146.

[132] Reuters. Available online: https://www.reuters.com/article/us-germany-beer/germanbeer-purity-in-question-after-environment-group-finds-weed-killer-tracesidUSKCNOVY222 (Accessed on 03 July 2021).

[133] Rubio, F., Guo, E., Kamp, L. (2014): Survey of glyphosate residues in honey, corn and soy products. - Journal of Environmental and Analytical Toxicology 5: 1-8.

[134] Sammons, R. D., Gaines, T. A. (2014): Glyphosate resistance: state of knowledge. - Pest Management Science 70: 1367-1377.

[135] Samsel, A., Seneff, S. (2013): Glyphosate, pathways to modern diseases II: Celiac sprue and gluten intolerance. - Interdisciplinary Toxicology 6(4): 159-184.

[136] Sasal, M. C., Demonte, L., Cislaghi, A., Gabioud, E. A., Oszust, J. D., Wilson, M. G., Michig, N., Beldoménico, H. R., Repetti, M. R. (2015): Glyphosate loss by runoff and its relationship with phosphorus fertilization. - Journal of Agricultural and Food Chemistry 63(18): 4444-4448.

[137] Savin, M. C., Purcell, L. C., Daigh, A., Manfredini, A. (2009): Response of mycorrhizal infection to glyphosate applications and P fertilization in glyphosate-tolerant soybean, Maize, and Cotton. - Journal of Plant Nutrition 32(10): 1702-1717.

[138] Schinasi, L., Leon, M. E. (2014): Non-hodgkin lymphoma and occupational exposure to agricultural pesticide chemical groups and active ingredients: A systematic review and meta-analysis. - International Journal of Environmental Research and Public Health 11(4): 4449-4527. 
[139] Sergiev, I. G., Alexieva, V. S., Ivanov, S. V., Moskova, I. I., Karanov, E. N. (2006): The phenylurea cytokinin 4PU-30 protects maize plants against glyphosate action. - Pesticide Biochemistry and Physiology 85: 139-146.

[140] Serra, A. A., Nuttens, A., Larvor, V., Renault, D., Couée, I., Sulmon, C., Gouesbet, G. (2013): Low environmentally relevant levels of bioactive xenobiotics and associated degradation products cause cryptic perturbations of metabolism and molecular stress responses in Arabidopsis thaliana. - Journal of Experimental Botany 64: 2753-2766.

[141] Shitha, C. R. (2014): Impact of glyphosate and chlorpyriphos on chemical and biological properties of lateritic soil. - Master Thesis, Kerala Agricultural University, India.

[142] Silva, V., Montanarella, L., Jones, A., Fernández-Ugalde, O., Mol, H. G. J., Ritsema, C. J., Geissen, V. (2018): Distribution of glyphosate and aminomethylphosphonic acid (AMPA) in agricultural topsoils of the European Union. - Science of the Total Environment 621: 1352-1359.

[143] Singh, S., Kumar, V., Datta, S., Wani, A. B., Dhanjal, D. S., Romero, R., Singh, J. (2020): Glyphosate uptake, translocation, resistance emergence in crops, analytical monitoring, toxicity and degradation: a review. - Environmental Chemistry Letters 18: 663-702.

[144] Slow Food: Available online: https://www.slowfood.com/stop-glyphosate-say-noherbicide-healths-sake/ (Accessed on 03 July 2021).

[145] Stellin, F., Gavinelli, F., Stevanato, P., Concheri, G., Squartini, A., Paoletti, G. M. (2018): Effects of different concentrations of glyphosate (Roundup 360®) on earthworms (Octodrilus complanatus, Lumbricus terrestris and Aporrectodea caliginosa) in vineyards in the North-East of Italy. - Applied Soil Ecology 123: 802-808.

[146] Székács, A., Darvas, B. (2012): Forty years with glyphosate. - Department of Ecotoxicology and Environmental Analysis, Plant Protection Institute, Hungarian Academy of Sciences Hungary: Budapest, Hungary, pp. 247-284.

[147] Székács, A., Darvas, B. (2018): Re-registration challenges of glyphosate in the European Union. - Frontiers in Environmental Science 6: 78.

[148] Tani, E., Chachalis, D., Travlos, I. S., Bilalis, D. (2016): Environmental conditions influence induction of key ABC-Transporter genes affecting glyphosate resistance mechanism in Conyza canadensis. - International Journal of Molecular Science 17: 342.

[149] Tejada, M. (2009): Evolution of soil biological properties after addition of glyphosate, diflufenican and glyphosate+diflufenican herbicides. - Chemosphere 76(3): 365-373.

[150] Test-Salvagente (2016): Stop Alla Roulette Russa del Glifosato. - Available online: https://glifosato.it/\#altro (Accessed on 03 July 2021).

[151] Thongprakaisang, S., Thiantanawat, A., Rangkadilok, N., Suriyo, T., Satayavivad, J. (2013): Glyphosate induces human breast cancer cells growth via estrogen receptors. Food and Chemical Toxicology 59: 129-136.

[152] Torretta, V., Katsoyiannis, I. A., Viotti, P., Rada, E. C. (2018): Critical review of the effects of glyphosate exposure to the environment and humans through the food supply chain. - Sustainability 10: 950.

[153] Travlos, I. S., Cheimona, N., Bilalis, D. (2017): Glyphosate efficacy of different salt formulations and adjuvant additives on various weeds. - Agronomy 7: 60.

[154] Travlos, I. S., Cheimona, N., De Prado, R., Jhala, A. J., Chachalis, D., Tani, E. (2018): First case of glufosinate-resistant rigid ryegrass (Lolium rigidum Gaud.) in Greece. Agronomy 8: 35.

[155] U.S. Environmental Protection Agency (USEPA): Draft risk assessments for glyphosate. - Available online: https://www.epa.gov/pesticides/epa-releases-draft-risk-assessmentsglyphosate (Accessed on 03 July 2021).

[156] U.S. Environmental Protection Agency (USEPA) (2019): Proposed Interim Registration Review Decision Case No. 0178. - April, 2019. https://www. epa.gov/sites/production /files/2019-04/documents/glyphosate-pid-signed. pdf. (Accessed on 07 September 2020). 
[157] Vera, M. S., Lagomarsino, L., Sylvester, M., Pérez, G. L., Rodríguez, P., Mugni, H., Sinistro, R., Ferraro, M., Bonetto, C., Zagarese, H., Pizarro, H. (2010): New evidences of Roundup ${ }^{\circledR}$ (glyphosate formulation) impact on the periphyton community and the water quality of freshwater ecosystems. - Ecotoxicology 19(4): 710-721.

[158] Vereecken, H. (2005): Mobility and leaching of glyphosate: A review. - Pest Management Science 61: 1139-1151.

[159] Verrell, P., Van Buskirk, E. (2004): As the Worm Turns: Eisenia fetida Avoids Soil Contaminated by a Glyphosate-Based Herbicide. - Bulletin of Environmental Contamination and Toxicology 72(2): 219-224.

[160] Viator, R. P., Underbrink, S. M., Jost, P. H., Witten, T. K., Cothren, J. T. (2000): Factors affecting roundup ready ${ }^{\circledR}$ cotton fruit retention and yields. - In: Proceedings Beltwide Cotton Conferences, 2000.

[161] Vivancos, P. D., Driscoll, S. P., Bulman, C. A., Ying, L., Emami, K., Treumann, A., Mauve, C., Noctor, G., Foyer, C. H. (2011): Perturbations of amino acid metabolism associated with glyphosate-dependent inhibition of shikimic acid metabolism affect cellular redox homeostasis and alter the abundance of proteins involved in photosynthesis and photorespiration. - Plant Physiology 157: 256-268.

[162] Wang, S., Seiwert, B., Kästner, M., Miltner, A., Schäffer, A., Reemtsma, T., Yang, Q., Nowak, K. M. (2016): (Bio)degradation of glyphosate in water-sediment microcosms - A stable isotope co-labeling approach. - Water Research 99: 91-100.

[163] Weaver, M. A., Krutz, L. J., Zablotowicz, R. M., Reddy, K. N. (2007): Effects of glyphosate on soil microbial communities and its mineralization in a Mississippi soil. Pest Management Science 63(4): 388-393.

[164] Williams, G. M., Kroes, R., Munro, I. C. (2000): Safety evaluation and risk assessment of the herbicide Roundup and its active ingredient, glyphosate, for humans. - Regulatory Toxicology and Pharmacology 31: 117-165.

[165] Yanniccari, M., Tambussi, E., Istilart, C., Castro, A. M. (2012): Glyphosate effects on gas exchange and chlorophyll fuorescence responses of two Lolium perenne L. biotypes with differential herbicide sensitivity. - Plant Physiology and Biochemistry 57: 210-217.

[166] Yanniccari, M., Gómez-Lobato, M. E., Istilart, C., Natalucci, C., Giménez, D. O., Castro, A. M. (2017): Mechanism of resistance to glyphosate in Lolium perenne from Argentina. - Frontiers in Ecology and Evolution 5: 123.

[167] Zabaloy, M. C., Garland, J. L., Gómez, M. A. (2008): An integrated approach to evaluate the impacts of the herbicides glyphosate, 2,4-D and metsulfuron-methyl on soil microbial communities in the Pampas region, Argentina. - Applied Soil Ecology 40(1): 1-12.

[168] Zabaloy, M. C., Allegrini, M., Tebbe, D. A., Schuster, K., Gomezb, E. V. (2017): Nitrifying bacteria and archaea withstanding glyphosate in fertilized soil microcosms. Applied Soil Ecology 117-118: 88-95.

[169] Zabalza, A., Orcaray, L., Fernández-Escalada, M., Zulet-González, A., Royuela, M. (2017): The pattern of shikimate pathway and phenylpropanoids after inhibition by glyphosate or quinate feeding in pea roots. - Pesticide Biochemistry and Physiology 141: 96-102.

[170] Zablotowicz, R. M., Reddy, K. N. (2004): Impact of glyphosate on the Bradyrhizobium japonicum symbiosis with glyphosate-resistant transgenic soybean: A minireview. Journal of Environmental Quality 33(3): 825-831.

[171] Zhan, H., Feng, Y., Fan, X., Chen, S. (2018): Recent advances in glyphosate biodegradation. - Applied Microbiology and Biotechnology 102(12): 5033-5043.

[172] Zobiole, L. H. S., Oliveira, R. S., Kremer, R. J., Constantin, J., Yamada, T., Castro, C., Oliveira, F. A., Oliveira Jr., A. (2010): Effect of glyphosate on symbiotic $\mathrm{N}_{2}$ fixation and nickel concentration in glyphosate-resistant soybeans. - Applied Soil Ecology 44: 176180 . 
[173] Zobiole, L. H. S., Kremer, R. J., Oliveira, R. S., Constantin, J. (2011): Glyphosate affects chlorophyll, nodulation and nutrient accumulation of "second generation" glyphosateresistant soybean (Glycine max L.). - Pesticide Biochemistry and Physiology 99: 53-60.

[174] Zobiole, L. H. S., Kremer, R. J., de Oliveira Jr., R. S., Constantin, J. (2012): Glyphosate effects on photosynthesis, nutrient accumulation, and nodulation in glyphosate-resistant soybean. - Journal of Plant Nutrition and Soil Science 175: 319-330. 